\title{
The Relationship between Organization Strategy, Fixed-Assets Investment and Earnings Quality
}

\author{
Shen-Ho Chang \\ Department of Accounting, Feng Chia University, Taiwan \\ No. 100, Wenhwa Rd., Seatwen, Taichung, Taiwan 40724 \\ E-mail: shchang@fcu.edu.tw \\ Teng-Shih Wang \\ Program in Business, Feng Chia University, Taiwan \\ No. 100, Wenhwa Rd., Seatwen, Taichung, Taiwan 40724 \\ E-mail: t.swang0617@gmail.com \\ Shaio Yan Huang (Corresponding Author) \\ Advanced Institute of Manufacturing with High-Tech Innovations \\ Department of Accounting and Information Technology \\ National Chung Cheng University,
}

No. 168 University Rd., Minhsiung Township, Chiayi County 62102, Taiwan

E-mail: actsyh@yahoo.com.tw

An-An Chiu

Department of Accounting and Information Technology

National Chung Cheng University

No. 168 University Rd., Minhsiung Township, Chiayi County 62102, Taiwan

E-mail: ananchiu2009@gmail.com

Received: June 2, 2013 Accepted: June 20, 2013 Published: June 20, 2013

doi:10.5296/ajfa.v5i1.3802ＵRL: http://dx.doi.org/10.5296/ajfa.v5i1.3802

\section{Abstract}

One of the important sources for investors to evaluate is the information provided in the 
financial statements disclosed by firms. Past researches consider that worse financial statement quality has higher information risks from the aspect of information risks but they ignore the investors' degree of tolerance and aversion towards risks. Furthermore, the accounting signals hidden behind financial statements can be considered as important information for investors to evaluate the futurity of enterprises. Thus, it is our main research topic as how to apply accounting signals on investment risks. This study uses data of the U.S. during 1991-2008 to review the influence of accounting signals on investment risks. Result finds that in the investment management essentials in firm-wise, the accounting signals for capital expenditure ratio per person can lower the investment risks no matter in cost leadership firms or differentiation strategy firms. For the investment management essentials in industry-wise, we have the below findings: In cost leadership strategy samples, there is competitive convergence if enterprises over-pursue the fixed asset turnover ratio. In the samples that adopt differentiation strategy, increasing the ixed asset turnover ratio can enhance organization's competitiveness and reduce investment risks. This is the first study that applies capability index of accrual quality (investors' degree of tolerance and aversion towards risks) on researches of accounting signals and discovers that competitive convergence exists in organizations that adopt cost leadership strategy.

Keywords: Earning Quality, Investment Risks, Accounting Signals, Organization strategy, Competitive Convergence 


\section{INTRODUCTION}

This study is an extension of the research of Soliman (2008) and a review of the influence of accounting signals on investment risks. Investment risks are defined as the risks of investors' uncertainty on future investment or investment losses. In another word, investors invest in securities based on the information on financial statements disclosed by company managers and such investment causes uncertainty. It is suggested that the acquisition and use of information on financial statements is regarded as one of the methods to reduce investment risks. For example, market participants can assess a firm's capability of solvency and liquidity through the cash flows information; or, to conduct business valuation using accruals in earnings. However, earnings information can have estimated errors under intentional or unintentional management of managers. Francis, LaFond, Olsson and Schipper (2005) pointed out intentional error was caused by the earnings management of managers whereas unintentional error was caused by management lapses and environmental uncertainty.

Not to mention whether such errors are caused by the intentions of managers, the measurement errors for accruals will affect accrual quality and lead to two results: 1. Earnings after tax will diverge from the actual cash receipts; 2. The more the undetected estimated errors included in earnings after tax, the higher the uncertainty is. Therefore, investors use financial information that includes uncertain accrual items during investment decision-making process when they are not disclosed with full information and there are risks caused by the uncertainty. This is called investment risks. In the past, standard deviation of residuals for regression model has been the major measurement of investment risks (e.g Francis et al., 2005; Core, Guay and Verdi, 2008 ; Kim \& Qi, 2010; Mashruwala \& Mashruwala, 2011). For investors, however, assessment of investment risks should consider the degree of tolerance and aversion towards risks instead of the information risks of objects. Chang, Huang, Chiu and Huang (2012) established a Basic Capability Index of Accrual Quality, as know as $\mathrm{C}_{\mathrm{BAQ}}$ with loss function in mathematical model deduction. The index is built based on investors' degree of tolerance and aversion towards risks. It also found that higher the capability index of basic accrual quality, the lower the investment risks.

Investors should also respect the accounting signals from firms while considering information risks and their degree of tolerance and aversion towards risks. The earnings information provided in financial statements is an important reference on the capital market for investors. Nissim and Penman (2001) were the first to convert accounting-based valuation analysis to option-based analysis and pointed out current financial indicators in the analysis of current financial statement can be seen as current ratios as predictors of the future ratios that determine equity payoff. Soliman (2008) used DuPont Analysis to point out the accounting signals in the analysis in fact provides incremental information about firm's characteristics. In long term, the accounting signals also provide market participants the incremental information about future earnings. This paper thinks the accounting signals financial indicators from DuPont Analysis can reflect the current operation situation of a firm but there are few researches on its relationship with the investment risks evaluated by investors. Hence, we attempt to combine the accounting signals obtained from DuPont Analysis and review 
their relation.

To review our research topics, we apply the capability index of accrual quality that considers investors' degree of tolerance and aversion towards risks established by Chang et al.(2012) and take this as the proxy for investment risks. Afterwards, we review whether the capability index of accrual quality used in this paper has the same propensity as the accrual quality by the firm characteristics variable proposed by Dechow and Dichev (2002) and verify the usefulness of capability index of accrual quality as investment risks. Then, we will break down two levels of accounting signals indicators using DuPont Analysis - strategy level and internal management level - and review their relationship with investment risks. Our results show that firm scale is positively associated with the capability index of accrual quality that means larger firms have more stable operations which will reduce estimated errors and investment risks. Standard deviation of revenue, standard deviation of cash flows and number of surplus are negatively associated. When the firms face environment with higher uncertainty or greater number of surplus, the investment risks will increase. For the influence of investment management on investment risks, we find that the increase respect on automation can reduce risks no matter the firms adopt cost leadership or differentiation strategies if we put aside industry effect in investment management. The enhancement in automation helps firms to adapt to uncertainty in the environment. In samples adopt cost leadership strategy, there is competitive convergence proposed by Porter (1996) if enterprises over-pursue the turnover of fixed assets. That means enterprises will have similar strategy if they improve quality, production cycle and relationship with partners and vendors by simulating each other. This will result in deterioration where there is no winner in the market so the investment risks increase. In the samples that adopt differentiation strategy, increasing the turnover of fixed assets can enhance organization's competitiveness and reduce investment risks. When we inspect the relation between investment management and investment risks, this study interprets that no matter which strategy is adopted - cost leadership or differentiation - the enhancement of automation equipment should be taken into consideration. For firms that adopt cost leadership strategy, the use of automatic production can reduce the uncertainty factors from non-fixed assets and investment risks in the case of low gross profit rate. On the contrary, in the case of high gross profit rate, firms adopt differentiation strategy can adjust production methods in a speed that surpasses the industry by automatic production and provide better differentiated products or services to customers.

The major contribution of this study is to consider investors' degree of tolerance and aversion towards risks in the capability index of accrual quality and apply it on the research of firm's accounting signals. Different from past researchers which only adopt standard deviation of residuals as the measurement of information risk, this study not only considers the degree of tolerance and aversion towards risks in the capability index of accrual quality, but also applies it on the research of accounting signals analysis in capital market. This study also points out the influence of accounting signals input on investment risks. Rest of this paper includes literature review which addresses literature related to business valuation process, organization strategies, and accounting signals. Research design includes deduction of capability index of accrual quality, definitions of related variables and explanation of sources. 
Next will be empirical results which include descriptive statistics, regression analysis and sensitivity analysis. Last section is our conclusions and practical implications of this study.

\section{LITERATURE REVIEW}

\section{Organization Strategy and Business Valuation}

Organization strategies are like nautical maps which provide clear guidelines of the competitive markets for enterprises. Porter (1996) suggests that organization strategies should be classified as differentiation strategy and cost leadership strategy. Firms are able to maintain their differences with rivals by using strategies. Kaplan and Norton (2000) point out strategy map can assist employees to understand the relation between their jobs and organization's goals and how to achieve such goals by coordination and cooperation and also to create organization values by connecting organization assets. Palepu, Healy, Bernard and Peek (2007) mention organization strategy analysis is the starting point for the analysis of financial statement. It can be divided as industry choice, competitive positioning analysis and corporate strategy analysis. Competitive positioning analysis includes cost leadership and differentiation. These two strategies can both build continuous competitive advantages. Brealey, Myers and Allen (2011) note that economic rents ${ }^{1}$ are earned only at two points of time - when the industry has not settled down to equilibrium or when the firm has something valuable that competitor does not have. Therefore, the nature of organization strategies is to provide organization a clear guideline and create competitive advantages and create continuous advantages using strategies so to create more economic values.

Porter (1996) mentions a lot of organizations mix up organization strategies with operational effectiveness and take the operational effectiveness tools as organization strategies, so organization does not have sustainable advantages. Hence, he defines the relationship between organization strategies and operational effectiveness. Both of them are the basic requirements to achieve superior performance of organization. Organization strategies can help organization to outperform its rivals - normally through cost leadership or differentiation. Operational effectiveness means performing similar activities better than rivals perform them. In the discussion of organization strategy maps, Kaplan and Norton (2000) think to increase shareholder value, revenue growth and productivity should be addressed. Revenue growth focuses on introducing new sources of revenue and increase customer profitability; while productivity focuses on improving the cost structure and use of assets. Palepu et al. (2007) suggest value of a firm is determined by its profitability and growth from the aspect of business valuation. The firm's profitability and growth are influenced by its product market and financial market strategies. The product market strategies are implemented through the firm's competitive strategy, operating policy and investment decisions while financial market strategies are implemented through financing and dividend policy.

Fairfield and Yohn (2001) mention the return on assets can be decomposed into asset turnover and profit margin. Compared with current profitability, it is more useful to provide the

\footnotetext{
${ }^{1}$ Economic rents are the profit that cover the cost of capital.(Brealey et al., 2011)
} 
insights into the firm's strategy with asset turnover and profit margin. Soliman (2008) believes the accounting signals in the DuPont Analysis can be the variables to measure the firm's operation structure. In particular, the analysis decomposes a firm's return on net operating assets (RNOA) into profit margin (PM) and asset turnover (ATO) where PM is often derived from pricing power, for example product innovation, product positioning, brand name recognition, first mover advantage, and market niches. ATO measures asset utilization and efficiency, which generally comes from the efficient use of property, plant, and equipment; efficient inventory processes; and other forms of working capital management. Therefore, the information provided by financial statements assists external investors, analysts and creditors to further understand the current strategy position and operation conditions of a firm. Palepu et al. (2007) also mention that the purpose of ratio analysis is to evaluate the effectiveness of the firm's policies. It can also help analyst regarding the firm performance and prospect.

\section{Business Valuation Theories and Accounting Signals}

The main target of financial statements is to understand the determinant factor of a firm's value. Ohlson (1995) indicates that the value of a firm can be expressed as a function of the firm's book value and future abnormal earnings, or future return on equity in excess of the cost of capital. On the other hand, Nissim and Penman (2001) point out that financial statements state the equity value of a firm and it is determined by future earnings power. Soliman (2008) uses the residual income model to show stock price can be rewritten in terms of ROE and reported book value plus an infinite sum of discounted residual income, as equation (1):

$$
P_{t}=B_{t}+\sum_{i=1}^{\infty} E_{t}\left[\left(R^{\prime} E_{t+1}-r_{e}\right) B_{t+i-1}\right] /\left(1+r_{e}\right)^{i}
$$

where,

$\mathrm{P}_{\mathrm{t}}$ : stock price in $\mathrm{t}$ period

$\mathrm{B}_{\mathrm{t}}$ : reported book value in $\mathrm{t}$ period

$\mathrm{E}_{\mathrm{t}}(\mathrm{.})$ : expectation that provide information in t period

$\mathrm{ROE}_{\mathrm{t}+1}$ : return on equity in $\mathrm{t}+1$ period

$\mathrm{E}_{\mathrm{t}}\left(\mathrm{D}_{\mathrm{t}+\mathrm{i}}\right)$ : expected future dividends in $\mathrm{t}+1$ period based on the information that can be provided in $\mathrm{t}$ period

$\mathrm{r}_{\mathrm{e}}$ : cost of equity capital

Ohlson (1995) and Feltham and Ohlson (1995) highlight the theoretical importance of ROE in business valuation. Fairfield and Yohn (2001) mention that net operating return on assets can be decomposed into asset turnover and profit margin. Asset turnover measures the firm's ability to generate revenues from its assets while profit margin measures the firm's ability to control the costs incurred to generate the revenue. They are both part of the firm's strategy. Palepu et al. (2007) point out that ROE is the starting point of a systematic analysis of a 
firm's performance and it is the comprehensive indicator for firm's performance which provides managers the information on employing its assets profitably and generating returns. ROE can be decomposed into ROA and a measure of financial leverage. Soliman (2008) uses the DuPont Analysis to decompose ROE into the three multiplicative ratios of Profit Margin, Asset Turnover, and Leverage. The decomposition is shown as equation (2):

$$
\text { ROE }=\text { ROA } \times \text { Financial Leverage }=\frac{\text { NI }}{\text { Sales }} \times \frac{\text { Sales }}{\text { Assets }} \times \frac{\text { Assets }}{\text { BVEquity }}
$$

Palepu et al. (2007) mention firm's growth and profitability are influenced by its product market and financial market strategies. The product market strategies is implemented through the firm's competitive strategy, operating policy (including managing revenue and expenses) and investment decisions (including managing working capital and fixed assets). Financial market strategy ate implemented through financing (including managing liabilities and equity) and dividend policy (including managing payout). Porter (1996) mentions that organization strategy and operating effectiveness are essential for superior performance. Thus, this paper will focus on the decomposition of ROA and the presentation of product market strategy as well as the operating and financial policies.

For business strategies, Porter (1996) indicates the establishment of differences with rivals to stand out in the crowd. The two methods to stay different with rivals are providing customers with higher values and providing lower costs but with the same values of the rivals. Nissim and Penman (2001) use the decomposition of RNOA and have the following results: PM measures the firm's ability to control the costs incurred to generate sales and gives insight into the sensitivity of operating income to product price and cost structure. ATO captures the firm's efficiency in using operating assets to generate sales and is often interpreted as a measure of asset utilization by managers. Fairfield and Yohn (2001) also point out that profit margin, reflects the firm's operating efficiency while asset turnover reflects the firm's asset utilization. For example, discount stores tend to have relatively higher asset turnovers and lower profit margins than luxury or specialty stores. Palepu et al. (2007) mention a firm following the differentiation strategy seeks to be unique in its industry with product that is positioned to be highly valued by customer. On the other hand, cost leadership achieves superior performance by economics of scale and scope, economies of learning, efficient production, simpler product design, lower input costs, and efficient organizational processes. Soliman (2008) points out that PM and ATO present different structures about a firm's operations. PM is often derived from pricing power, such as product innovation, product positioning, brand name recognition, first mover advantage, and market niches. ATO measures asset utilization and efficiency, which generally comes from the efficient use of property, plant, and equipment; efficient inventory processes; and other forms of working capital management. There are two sources to affect ATO and PM differently from competitiveness aspect. Large profit margins often draw new entrants into the marketplace or quick imitation of new ideas from existing rivals resulting in high profit margins reverting to normal levels. Unlike profit margin, however, asset turnover is more difficult to imitate another firm's efficient production processes so it is not threatened by rivals easily. Hence, 
this paper thinks a relative proportion of PM and ATO can distinguish organization strategies with ROA. Firm with larger profit margins and lower asset turnover will tend to differentiation while firms with lower profit margins and higher asset turnover will tend to cost leadership.

Palepu et al. (2007) indicate gross margin is influenced by two factors: 1) the price premium that a firm's products or services command in the marketplace and 2) the efficiency of the firm's procurement and production process in terms of operating management. In terms of investment management, it is divided into working capital management and management of non-current assets. Operating working capital focuses on trade receivables, inventories and trade payable. They are short-term investment management which influences the normal operation of a firm. Another area of investment management concerns the utilization of a firm's non-current asset which is long-term management. This paper employs hierarchical decomposition of ROA and classifies fixed asset turnover ratio and capital expenditure ratio per person as non-current assets. Fixed asset turnover ratio measures if a firm can use fixed assets to create benefits. Capital expenditure ratio per person determines if a firm uses high technology equipment in production. When a firm has higher fixed asset turnover ratio, that means it can effectively use fixed asset equipment and improve its ROA. When the firm has higher capital expenditure ratio per person, it can react to the environment uncertainties quickly and create more values with the assistance of high technology.

\section{Accounting Signals and Investment Risks}

Healy and Palepu (2001) think asymmetric information and incentive problems lead to managers and outside investors' demand on financial reports and disclosure of finance. Beaver (2002) indicates information on financial statements presents clear and related standard for decision makers in making decisions and for the individual parties to make contracts. For investors, the earnings information on financial statements evaluates the results of managers for the past year (Nwaeze, Yang and Tin, 2006; Banker, Huang and Natarajan, 2009) and updates its judgment on the firm's value. Kothari (2000) mentions market participants seek high-quality financial information because it mitigates information asymmetry between the management of the firm and outside investor. Reduced information asymmetry has desirable effects on the cost of capital and the volatility of security prices. Hence, investors and analysts can understand the managers' efforts and current value of a firm and obtain desirable returns on equity with the information on financial statements.

Beaver (1998) argues that one theoretical link between earnings and share prices is that current earnings provide information to predict future earnings. Lev and Thiagarajan (1993) show that signals of the current accounting data can predict future earnings change. These signals include information about changes in inventories, accounts receivables, gross margins, selling expenses, capital expenditures, etc. Abarbanell and Bushee (1998) find that fundamental signals provide information about future returns that is associated with future earnings news by fundamental accounting analysis. Nissim and Penman (2001) believe profitability and growth are the driven forces for equity values. They also lay out a structured financial statement to analyze that profitability and growth facilitate forecasting and valuation. Soliman (2008) finds that the information in the accounting signal is in fact incremental to 
accounting signals in predicting future earnings by the DuPont Analysis. In conclusion, fundamental accounting signals on financial statements can assist investors to understand the internal strategies of organization, allocation of assets and profitability and provide incremental to accounting signals for investors to predict future earnings.

To enhance the profitability information, GAAP allows managers to mitigate the timing and matching issues of cash basis by accrual processes in order to reflect the earnings of organization. Therefore, the composition of earnings can be divided into accruals and cash flows. Accruals focus on the timing of income and expenditures that are recognized in earnings, while cash flows focus on cash income and expenditure on a cash basis. Dechow and Dichev (2002) think that accruals shift or adjust the recognition of cash flows over time so the adjusted numbers can better measure a firm's performance. However, accruals are frequently based on assumptions and estimates that, if wrong, must be corrected in future accruals and earnings. The estimation errors and their subsequent corrections will reduce the beneficial role of accruals. McNichols (2002) classifies accounting literature regarding earnings quality into three categories: 1 . earnings are defined as high quality if earnings are persistent, an attribute based solely on the time-series properties of earnings. 2. Earnings are defined as high quality if earnings accurately represent the economic implications of underlying transactions and events. 3. Earnings quality is defined in terms of the relation between accruals and cash flows. Hence, this paper defines information risk as risks that incurred because investors make their decisions using accruals that include uncertainties. If the earnings quality is good, it will reduce the asymmetry in information between managers and investors. Reversely, the asymmetry in information between managers and investors will increase if earnings quality is poor. Nonetheless, market participants should not only rely on the information risks of the object itself, they should also consider their degree of aversion and tolerance towards risks. In addition, they should evaluate a firm's decision positioning, business value and investment risks by accounting signals. Thus, this paper will review the influence of accounting signals on investment risks by decomposition.

\section{Research Design}

\section{Empirical Model}

Past researches believe the use of accounting signals help investors or analysts to understand the organization operations and predict future earnings (e.g. Lev \& Thiagarajan, 1993; Abarbanell \& Bushee, 1998; Nissim \& Penman, 2001; Fairfield \& Yohn, 2001; Soliman, 2008). Soliman (2008) proposed a way that investors can reduce asymmetric information in accounting signals. By the decomposition of the DuPont Analysis model, market investors could get superior performance using the DuPont model while analysts could correct their prediction by the DuPont components. However, whether a firm's financial statement can reflect the true value is the most concerned information for outside investors who pursue for high earnings quality. To enhance the earnings information quality for assisting investors or shareholders in valuating managers' performance, GAAP allows managers to mitigate the timing and matching issues of cash basis by accrual processes in order to reflect the earnings of organization. Nevertheless, managers may mislead investors of the true business value intentionally which results in investment risks. Investment risks were measured mainly by accrual quality (residual standard deviation) in the past (Francis et al., 2005; Core et al., 2008; 
Kim \& Qi, 2010; Mashruwala \& Mashruwala, 2011) where worse accrual quality would lead to high information risks. However, for the investors, investment risks are defined as the uncertainty of losses incurred because investors make investment decisions based on the financial information disclosed by managers. So this paper regards investment risks as the ability that investors can tolerate the information risks. We consider the investors' tolerance range towards information risks instead of only the dispersion degree of information itself. This paper employs the estimation model of information risks proposed by Francis et al. (2005) with assistance of formulas of fundamental capability index of accrual quality by Chang et al. (2012) to probe the investment risks applied in this paper.

Dechow and Dichev (2002) suggested that estimate of the accrual quality requires a lengthy time-series. In addition, the regression approach requires information about future cash flows, which reduces its usefulness in model settings. Therefore, it is valuable to identify observable firm characteristics that act as instruments for the propensity to make estimation errors. This paper will adopt the firm characteristics suggested in this research, such as operation cycle, firm size, cash flows, revenues, earnings and number of deficits as variables to examine the influence of firm characteristics and investment risks. The regression model is as equation (3) below:

$$
C_{A Q i} \alpha f\left(\text { Ave.opcycle }_{i}, \text { Ave.size }_{i}, \text { Std. sale }_{i}, \text { Std.ocf }_{i}, \text { Std.Earnings }_{i}, \text { Prop.NI }_{i}\right)
$$

where,

$C_{A Q i}:$ Investment risks of i companies.

Ave.opcycle ${ }_{i}$ : Average operation turnover days of i companies.

Ave. size $_{i}$ : Average firm size of i companies.

Std.sale $i$ : Standard deviation of operation income of i companies.

Std.ocf: Standard deviation of cash flows of i companies.

Std.Earnings: Standard deviation of earnings of i companies.

Prop. $N I_{i}$ : Number of deficits of i companies.

After that, this paper reviews the influence of accounting signals on investment risks by DuPont components concept proposed by Soliman (2008). Different from the research model suggested by Soliman (2008), this paper first differentiates organization strategy level by profit ratio and asset turnover ratio in the DuPont components and probes the role that management plays in strategy level. Palepu et al. (2007) suggested that there were two types of internal management essentials, one is operations management, another is investment management. Operations management focuses on the short-term performance within the organization whereas investment management focuses on the assets management in long term. The investment risks index in this paper employs the accrual quality model proposed by Francis et al. (2005) with the assistance of the firm-specific regression estimate of the accrual quality in a lengthy time-series and the capability index of accrual quality. We obtain model (4) to review the probing questions in this paper:

$$
C_{A Q i} \alpha f\left(\text { Ave.fat }_{i}, \text { Ave.pce }_{i}, \text { Ave.fat_sic } C_{i}, \text { Ave.pcce_sic }_{i}, \text { Control }_{i} ; \text { Firm Strategy }_{i}\right)
$$


where,

$C_{A Q i}$ : Investment risks of i companies.

Ave.fat ${ }_{\mathrm{i}}$ : Fixed assets turnover ratio of i companies.

Ave.pce $_{\mathrm{i}}$ : Capital expenditure ratio per person of i companies.

Ave.fat_sic $\mathrm{c}_{\mathrm{i}}$ : Difference between fixed assets turnover ratio and industry average number of $\mathrm{i}$ companies.

Ave.pcce_sic : Difference between capital expenditure ratio per person and industry average number of i companies.

Controli: Control variable of i companies.

Firm Strategy: Firm strategy of i companies.

\section{Investment Risks under Capability Index of Accrual Quality}

Business value is the discount free cash flow of a firm in the future. Hence, investors tend to estimate a firm's future cash flows from the disclosed financial information. Nonetheless, financial information includes earnings information from two different accounting bases - net profit after tax on accrual basis and operating activities cash flows on cash basis. If the difference between these two is great it implies net profit per book is unable to receive cash. Accruals (e.g. estimation and assumption) are the major reason for the different. Therefore, accrual quality should also be considered for investment valuation. So this paper employs residuals to measure the method by accrual quality measurement method proposed by Francis et al. (2005), as shown in equation (5):

$$
\mathrm{TCA}_{\mathrm{i}, \mathrm{t}}=\phi_{0}+\phi_{1} \mathrm{CFO}_{\mathrm{i}, \mathrm{t}-1}+\phi_{2} \mathrm{CFO}_{\mathrm{i}, \mathrm{t}}+\phi_{3} \mathrm{CFO}_{\mathrm{i}, \mathrm{t}+1}+\phi_{4} \Delta \mathrm{Rev}_{\mathrm{i}, \mathrm{t}}+\phi_{5} \mathrm{PPE}_{\mathrm{i}, \mathrm{t}}+\varepsilon_{\mathrm{i}, \mathrm{t}}
$$

where, $\quad \mathrm{TCA}_{\mathrm{i}, \mathrm{t}}=\Delta \mathrm{CA}_{\mathrm{i}, \mathrm{t}}-\Delta \mathrm{CL}_{\mathrm{i}, \mathrm{t}}-\Delta \mathrm{Cash}_{\mathrm{i}, \mathrm{t}}+\Delta \mathrm{STDEBT}_{\mathrm{i}, \mathrm{t}}$ (total current accruals of $\mathrm{i}$ companies); $\Delta \mathrm{CA}_{\mathrm{i}, \mathrm{t}}$ Changes in current assets of $\mathrm{i}$ companies (Compustat \#4); $\Delta \mathrm{CL}_{\mathrm{i}, \mathrm{t}}$ Changes in current liabilities of $\mathrm{i}$ companies (Compustat \#5); $\Delta$ Cash $_{\mathrm{i}, \mathrm{t}}$ Changes in cash of i companies (Compustat \#1); $\Delta \mathrm{STDEBT}_{\mathrm{i}, \mathrm{t}}$ Changes in current liabilities due within one year of i companies (Compustat \#34); $\mathrm{CFO}_{\mathrm{i}, \mathrm{t}-1}$ Operating cash flows of i companies in t-1 period; $\mathrm{CFO}_{\mathrm{i}, \mathrm{t}}$ Operating cash flow of $\mathrm{i}$ companies in $\mathrm{t}$ period (Compustat \#308); $\mathrm{CFO}_{\mathrm{i}, \mathrm{t}+1}$ Operating cash flow of $\mathrm{i}$ companies in $\mathrm{t}+1$ period; $\Delta \operatorname{Rev}_{\mathrm{i}, \mathrm{t}}$ Changes in income of $\mathrm{i}$ companies in $\mathrm{t}$ period (Compustat \#12); $\mathrm{PPE}_{\mathrm{i}, \mathrm{t}}$ Assets, plants and equipment of $\mathrm{i}$ 
companies in t period respectively (Compustat \#7); $\varepsilon_{\mathrm{i}, \mathrm{t}}$ Residuals of i companies in t period 2 .

Dechow and Dichev (2002) used standard deviation of the residuals as a firm-specific measure of accrual quality, where a higher standard deviation signified lower quality. Chang et al. (2012) employed the investors loss function concept. When investors faced an investment target with multiple $\varepsilon_{t}$, the standard deviation incurred will hinder investors to measure its accrual quality. Therefore we should assume investors' tolerance range is a $90 \%$ probability distribution $^{3}$ formed by potential investment target. We will learn that the investors' tolerance range is 3.29 times standard deviation of the potential investment target and this is the numerator of capability index of accrual quality. Then we assume investor's investment criteria is to choose $\varepsilon_{\mathrm{t}}$ standard deviation of the investment target (as known as $\sigma_{\mathrm{P}}$ hereinafter) that equals to $\varepsilon_{\mathrm{t}}$ standard deviation of the potential investment target (as known as $\sigma_{\mathrm{T}}$ hereinafter) at the most. The measurement allowance of numerator of capability index of accrual quality is 3.29 times $\varepsilon_{\mathrm{t}}$ standard deviation of the investment target which is considered as the denominator of capability index of accrual quality. When the standard deviation of residuals for all potential investment targets and investment target are equal, the capability index of accrual quality should be 1 . This measurement index is called capability index of accrual quality in this paper ${ }^{4}$ (as known as $\mathrm{C}_{\mathrm{AQ}}$ hereinafter). Formula (6) is shown as:

$$
\mathrm{CAQ}=\mathrm{USL}-\mathrm{LSL} / 3.29 \sigma_{\mathrm{p}}
$$

where,

USL: Maximum tolerance incurred by $\varepsilon_{t}$ of the potential investment target (refer to $\left.\mathrm{USL}=\varepsilon_{T}+Z_{(1-\alpha / 2)} \sigma_{T}\right)$;

LSL: Minimum tolerance incurred by $\varepsilon_{t}$ of the potential investment target (refer to $\left.\mathrm{LSL}=\varepsilon_{T}-Z_{(1-\alpha / 2)} \sigma_{T}\right)$

$\varepsilon_{T}$ : Mean of $\varepsilon_{t}$ of the potential investment target (mean) ${ }^{5}$;

$\sigma_{T}$ : Standard deviation of $\varepsilon_{t}$ of the potential investment target (standard deviation);

\footnotetext{
2 Residuals are calculated by Firm- Specific Regression approach in this paper.

3 In statistics, probability distribution normally uses $90 \%, 95 \%$ and $99 \%$. The tolerance range formed by $90 \%$ probability distribution is narrower so we apply this as tolerance range $\varepsilon_{t}$.

${ }^{4}$ Different from research of Chang et al. (2012) which uses residuals estimation approach suggested by Dechow and Dichev (2002), we replace it by the estimation model of Francis et al.(2005).

5 This paper applies Firm-Specific Regression approach and regression assumption $\varepsilon_{T}=0$.
} 
$\sigma_{P}$ : Standard deviation of $\varepsilon_{t}$ of the potential investment target and assume $\sigma_{P}>0$.

Assume that USL and LSL remain unchanged while $\mathrm{C}_{\mathrm{AQ}}$ value and $\sigma_{\mathrm{P}}$ change in inverse direction. If $\varepsilon_{t}$ of the potential investment target is distributed discretely, $\sigma_{\mathrm{P}}$ is larger while $\mathrm{C}_{\mathrm{AQ}}$ value is smaller and vice versa. From now on, we include accrual quality into the tolerance range and decision rules of investors $\left(\sigma_{\mathrm{P}} \leqq \sigma_{\mathrm{T}}\right)$ which signifies accrual quality is extended as a capability index of accrual quality that can do relative comparison. Chang et al. (2012) suggested computing the $\mathrm{C}_{\mathrm{AQ}}$ of investment target to learn the accrual quality among investment targets when investors are choosing investment targets. In addition, investors can estimate the loss probability that incurs when $\varepsilon_{t}$ of investment target falls outside the tolerance range by the number of $\mathrm{C}_{\mathrm{AQ}}$ of investment target. Since this risk is caused by uncertainty, it is called Accrual Quality Measures of Investment Risks (named as $\mathrm{IR}_{\mathrm{i}}$ hereinafter). Capability index of accrual quality is converted into investment risk value so that investors can measure the degree of risk of a target within their investment criteria. In a normal assumption, investment risks are indicated as below ${ }^{6}$ :

$$
\begin{array}{r}
\mathrm{IR}_{i}=1-P\left(Z<\frac{U S L-\varepsilon_{T}}{\sigma_{T}}\right)+P\left(Z \leq \frac{L S L-\varepsilon_{T}}{\sigma_{T}}\right) \\
=2 P\left(Z \leq-1.645 C_{A Q}\right)
\end{array}
$$

In equation (7) we can learn that when $C_{A Q}$ value is greater, $I R_{i}$ value is smaller, which implies a lower investment risk. On the contrary, when $C_{A Q}$ value is smaller but $I_{i}$ value is greater, that implies a high investment risk. As long as we know the capability index of accrual quality we can have an insight into the investment risks. In another word, the difference between investors' prediction of investment target and the actual situation is huge because of the poor financial statement quality which leads to increased investment risks. Therefore, this paper considers capability index of accrual quality as investment risks of accrual quality measurement, that is, the standard deviation of residuals and investment risks of accrual quality measurement have corresponding mathematical relationship.

\section{Firm Characteristics Variable}

Dechow and Dichev (2002) mentioned that the estimation of accrual quality requires a lengthy time-series. In the regression approach requires information about future cash flows, which reduces its usefulness in the model settings. The observation of firm characteristics can be the instruments for the propensity to make estimation errors. Hence, this paper applies the variables from the model of Dechow and Dichev (2002) as firm characteristics measure

\footnotetext{
${ }^{6}$ When constructing $C_{A Q}$, we assume $\sigma_{T}=\sigma_{P}$.
} 
variables. They include average operating cycle $^{7}$, firm size (Compustat \#6), standard deviation of revenues (Compustat \#12), standard deviation of cash flows (Compustat \#308), standard deviation of earnings (Compustat \#172) and number of deficits. Dechow and Dichev (2002) pointed out longer operating cycles indicated more uncertainty, more estimation and errors of estimation. This paper thinks more estimation and errors of estimation will increase information risks and therefore increase investment risks. Dechow and Dichev (2002) expected large firms have more predictable and stable operations, and therefore less estimation errors. Hence, this paper thinks larger firms will have less investment risks. For standard deviation of revenues, Dechow and Dichev (2002) mentioned the volatility of revenues indicated higher uncertainty in the operating environment, and therefore large use of approximations and estimation, and reflected greater estimation errors. This paper believes that more uncertainty in operating environment causes more measurement errors and greater investment risks. Dechow and Dichev (2002) stated that cash flow can be a variable for uncertain operating environment. So this paper suggests that greater changes in cash flow will have higher investment risks. For the standard deviation of earnings, Dechow and Dichev (2002) pointed out that earnings are the sum of accruals and cash flows. Volatility of cash flows and accruals would lead to poor earnings quality. Hence, this paper believes higher standard deviation of earnings will have higher investment risks. Dechow and Dichev (2002) pointed out that losses were negative impact to a firm's operating environment. Accruals would involve continuous estimation errors. Hence, this paper thinks more frequent number of deficits in a firm will have higher investment risks.

\section{Organization Strategy in Accounting Signals and Management Factors}

To enhance a firm's value, managers pursue profitability and growth. Porter (1996) believed that organization strategy and operation performance could assist organization to improve its performance. This paper suggests that there are two levels for managers to improve performance from a business value aspect and they are strategy level and driving factor level. Strategy level includes differentiation strategy and cost leadership strategy. Poter (1985) mentioned that managers could ensure the firm maintains its competitiveness with the help of differentiation strategy and cost leadership strategy. Differentiation strategy is to differentiate the products with higher values and uniqueness in order to compete successfully. A firm that has high profit and lower asset turnover ratio tend to apply differentiation strategy. Cost leadership strategy is a firm achieving high effective use of assets to lower the costs and therefore wins market share. It is suitable for firms that have low profit but high asset turnover ratio $^{8}$. First, this paper decomposes profit margin which is decomposed by ROA into net profit margin and gross profit. The combination of gross profit ((Compustat \# 12Compustat \# 41)/ Compustat \# 12) and asset turnover ratio (Compustat \# 12/ Compustat \#6) can better present the strategy applied in a firm. This is called the strategy level in this paper.

\footnotetext{
${ }^{7}$ Operating cycle is inventory turnover days plus accounts receivable turnover days. Its formula is 360/(Cost of Goods Sold)/(Average Inventory)+360/(Sale/Average AR), where Sales (Compustat \# 12); Cost of Goods Sold (Compustat \# 41); AR (Compustat \# 2); Inventory (Compustat \# 3)

${ }^{8}$ Palepu et al. (2007) pointed cost leadership approach includes scale economy, effective production, simplified product design, low capital invested and effective organizational processes. However firms applying this approach may face low price competition from rivals and therefore their returns are lower. Similarly, Horngren, Datar and Rajan (2008) mentioned organization can achieve cost leadership by impoveing productivity and effectiveness, eliminating wastes and cost control.
} 
After that, we decompose asset turnover ratio into fixed asset turnover ratio (Compustat \# 12/ Compustat \#7) and capital expenditure ratio per person (Compustat \#7/ Compustat \#29). Fixed asset turnover ratio focuses on the effective use of fixed assets while capital expenditure ratio per person focuses on the investment of equipment, that is the degree of automation of a firm. The decomposition is shown as follows:

$$
\begin{aligned}
& \text { ROA }=\text { PM } \times \text { ATO } \\
& =\frac{\mathrm{NI}}{\text { Sales }} \times \frac{\text { Sales }}{\text { Assets }} \\
& =\frac{\text { NI }}{\text { Gross Pr ofit }} \times \frac{\overbrace{\text { Strategy Level }}^{\text {Gross Pr ofit }} \times \frac{\text { Sales }}{\text { Assets }}}{\text { Sales }} \times \frac{\text { Sales }}{\text { FixAssets }} \times \underbrace{\text { Employee }}_{\text {FixAssets }} \times \frac{\text { Employee }}{\text { Assets }}
\end{aligned}
$$

\section{Managerial Level}

Compared with past researchers which only considered firm-specific driving factor as measurement variable, this paper considers difference in industry mean as driving factor in order to review the firm-specific driving factors from industry aspect. Hence, we apply the mean of fixed asset turnover ratio (fixed asset turnover ratio is deducted by 3 digits of SIC) and the capital expenditure ratio per person (capital expenditure ratio per person is deducted by 3 digits of SIC) as the industry-specific driving factor variables.

\section{Sources}

Table 1 shows the data collection processes. Samples are collected from Compustat Research Insight. We collect data mainly base on the three dimensions in this paper and integrate the data into our regression model by matching. The study period is 1991 2008 ${ }^{9}$. For the collection processes of investment risks data, we collect 73,083 samples with search criteria: cash flows, properties, plants and equipment, changes in revenues, changes in current assets, changes in current liabilities, changes in cash, changes in current liabilities due within one year. There are 67,245 samples after exempting $1 \%$ of finance and insurance industry and extreme values. This study also matches the cash flows data of prior and later periods because they are involved in computing investment risks. So the samples left are 60,952. Lastly, we estimate residuals by firm-specific regression method so the longevity should be 8 years at

\footnotetext{
9 To accommodate the deflated total assets of prior period and cash flow data of prior and later periods, the data collection period is 1990 2009.
} 
least. After exempting 3,747 unqualified samples, we have 53,430 samples left.

Table 1. Sample selection

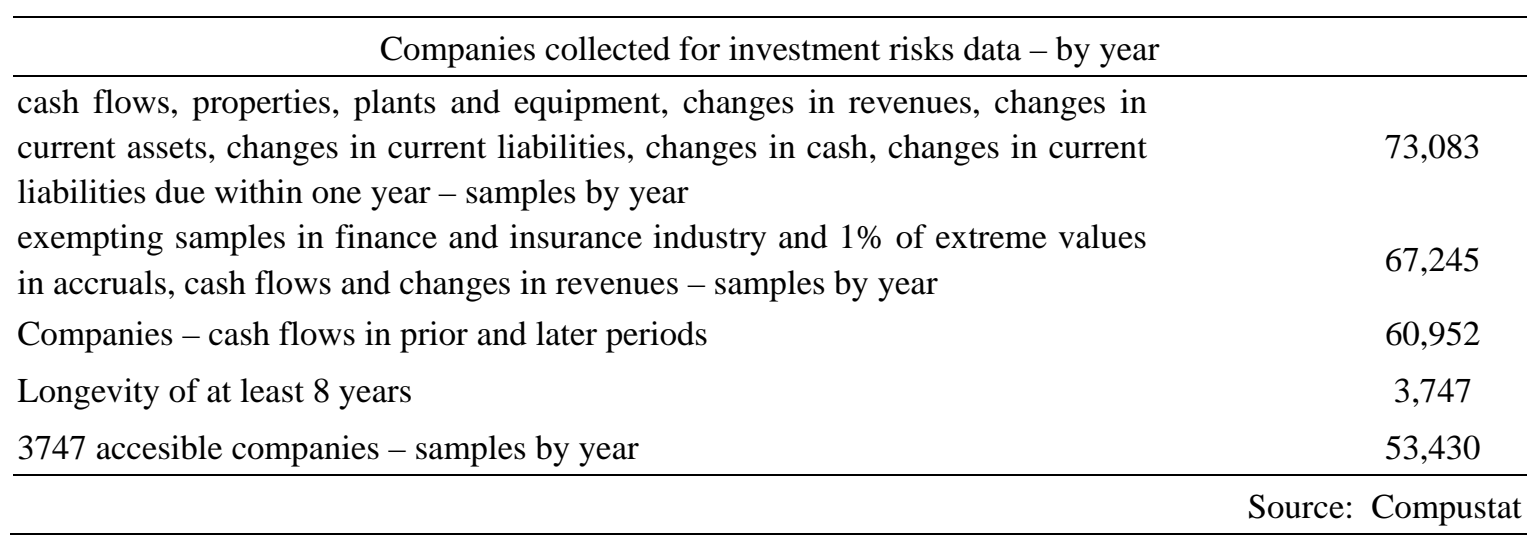

\section{Empirical Results}

Regression Analysis of CAQ and Firm Characteristics

We follow the research of Soliman (2008) to review the influence of accounting signals from asymmetric information on outside investors and propose the capability index of accrual quality as the proxy of investment risks from the loss function concept. To verify the effectiveness of the investment risks applied in this study, we employ the firm characteristics proposed by Dechow and Dichev (2002) as our testing variable to verify if its relationship with CAQ is consistent with past researches and test the relationship between accounting signals and investment risks.

Table 2 probes if the relationship between firm characteristics and investment risks we infer is the same as Dechow and Dichev (2002). Panel A is the basic descriptive statistics. The means for CAQ we infer and related firm characteristics such as operating cycles, firm size, standard deviation of revenues, standard deviation of cash flows, standard deviation of earnings and number of deficits are 6.055, 151.306, 5.778, 0.297, 0.100, 0.134 and 4.867 respectively; where CAQ, operating cycles and number of deficits are discretely distributed. Panel B is the correlation coefficient between CAQ and firm characteristics where we can learn that CAQ we infer shows positive correlation with firm size but it shows negative correlation with other firm characteristics.

Panel $\mathrm{C}$ is regression analysis of this paper. We can learn that CAQ and firm size are positively correlated which signifies that larger firm size will have greater CAQ. Larger firm is more stable in operations so the estimation errors are less and therefore reduces investment risks. Moreover, greater standard deviations of revenues or cash flows indicate higher uncertainty in the environment and therefore managers use more estimation and result in more estimation errors. The capability index of accrual quality becomes worse and investment risks are higher. In addition, the two variables of environment uncertainty show 
negative correlation with CAQ we infer. It implies when there is higher uncertainty in the environment, capability index of accrual quality becomes worse and investment risks are higher. When a firm has more deficits it is a negative impact to it. Capability index of accrual quality becomes worse and investment risks are therefore higher. The empirical result in this paper also indicates significant negative relationship between CAQ and number of deficits which signifies that higher number of deficits leads to higher investment risks. Therefore, the capability index of accrual quality we infer considering loss function concept is useful, and therefore we will conduct test analysis with accounting signals in next section.

Table 2. Descriptive Statistics and Correlation between the CAQ and Selected Firm Characteristics(n=3,335)

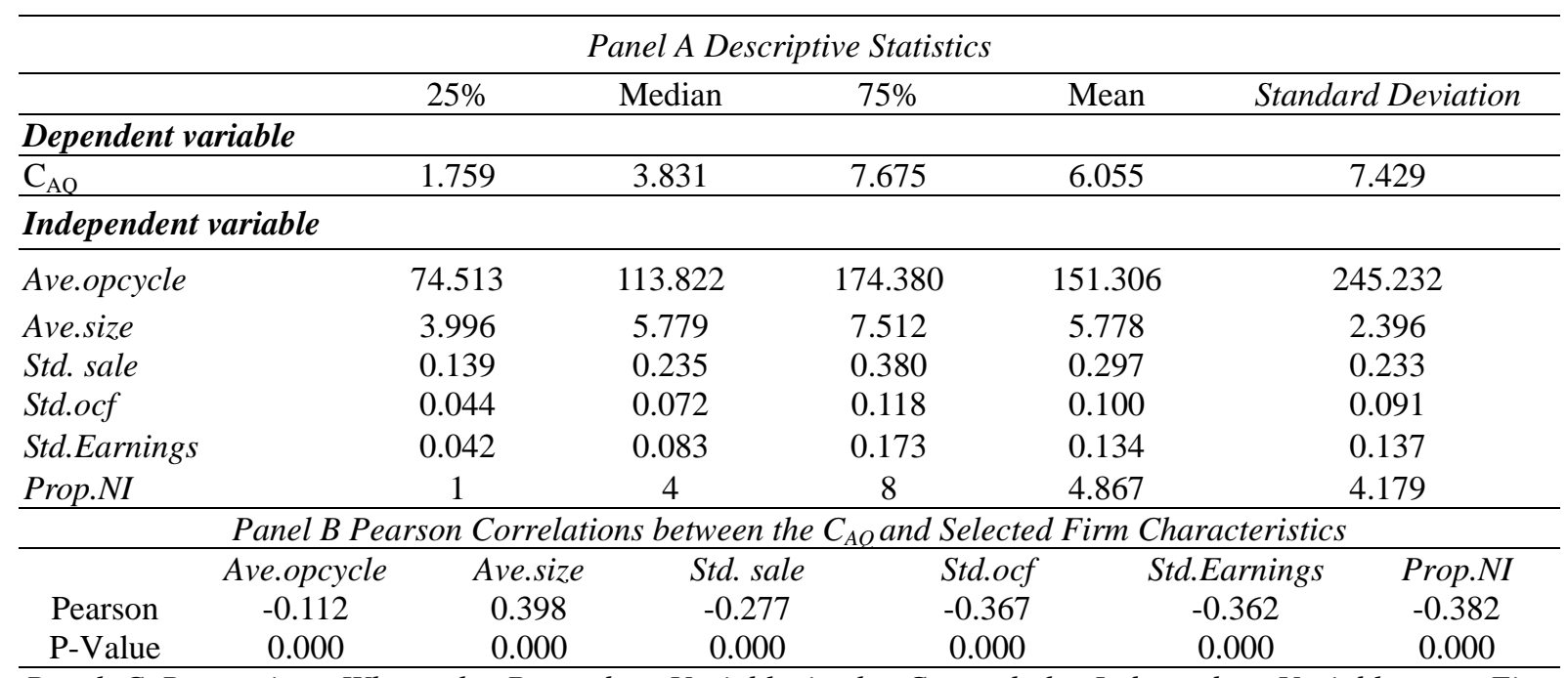

Panel C Regressions Where the Dependent Variable is the $C_{A Q}$ and the Independent Variables are Firm Characteristics

\begin{tabular}{ccccccccc}
\hline & Cons & Ave.opcycle & Ave.size & Std. sale & Std.ocf & Std.Earnings & Prop.NI & $\begin{array}{c}\text { Adi } \\
R^{\wedge} 2\end{array}$ \\
\hline Coef. & 6.068 & -0.001 & 0.599 & -3.204 & -7.638 & -0.010 & -0.343 & 0.214 \\
$\begin{array}{c}\text { P-Valu } \\
\text { e }\end{array}$ & 0.000 & 0.218 & 0.000 & 0.000 & 0.002 & 0.995 & 0.000 & \\
\hline Van & & & & &
\end{tabular}

Variable Definition: $\mathrm{C}_{\mathrm{AQ}}$ is the investment risks proposed by this study. It is the estimated residuals calculated by residuals estimation approach by Francis et.(2005) and is converted into the tolerance range of investors. Ave.opcycle Average operating cycles are calculated by inventory turnover days plus account receivable turnover days, the formula is 360/(Cost of Goods Sold)/(Average Inventory)+360/(Sale/Average AR); where, Sales (Compustat \# 12); Cost of Goods Sold (Compustat \# 41); AR (Compustat \# 2); Inventory (Compustat \# 3). It is then converted back into firm level by average. Ave.size is firm size. It is calculated by inputting total assets (Compustat \#6) into the natural logarithm function and converted back into firm level by average. Std. sale is standard deviation of revenues. Revenues are deflated by average total assets and obtained the standard deviation. Std.ocf is standard deviation of cash flows. Cash flows are deflated by average total assets and obtained the standard deviation. Std.Earnings is current earnings (Compustat \#172) deflated by average total assets and obtained the standard deviation. Prop.NI is the number of deficits. If current earnings equal to 1 , it is converted to firm level by accumulation.

\section{Regression Analysis of CAQ and Accounting Signals}

Next is a further test to structuralize the influence of accounting signals test on investment risks. Panel A in Table 3 is the descriptive statistics of samples in second phrase and Panel B is the Pearson correlation coefficient of all samples. For descriptive statistics (Panel A), the mean and standard deviation of CAQ are 5.975 and 7.156 respectively. The means of 
accounting signals are: 10.318 for fixed asset turnover ratio, 0.192 for capital expenditure ratio per person, -0.346 for difference between fixed asset turnover ratio and industry mean, -0.002 for difference between capital expenditure ratio per person and industry mean. For control variables, 5.788 for mean of firm size, 0.298 for mean of standard deviation of revenues, 0.100 for mean of standard deviation of cash flows, and 4.885 for mean of number of deficits.

Table 3. Descriptive Statistics and Correlation between the CAQ and Factors of Production(n=3,232) _ ROA Model

\begin{tabular}{|c|c|c|c|c|c|c|c|c|c|c|}
\hline \multicolumn{11}{|c|}{ Panel A Descriptive Statistics } \\
\hline & & & $25 \%$ & \multicolumn{2}{|c|}{ Median } & $75 \%$ & Mean & \multicolumn{3}{|c|}{ Standard Deviation } \\
\hline \multicolumn{11}{|c|}{ Dependent variable } \\
\hline \multicolumn{3}{|c|}{$\mathrm{C}_{\mathrm{AQ}}$} & 1.768 & \multicolumn{2}{|c|}{3.826} & 7.589 & 5.975 & \multicolumn{3}{|c|}{7.156} \\
\hline \multicolumn{11}{|c|}{ Independent variable } \\
\hline \multirow{4}{*}{\multicolumn{3}{|c|}{$\begin{array}{l}\text { Ave.fat } \\
\text { Ave.pce } \\
\text { Ave.fat_sic } \\
\text { Ave.pce_sic }\end{array}$}} & 2.221 & \multicolumn{2}{|c|}{5.482} & 12.011 & 10.318 & \multicolumn{3}{|c|}{14.635} \\
\hline & & & 0.018 & \multicolumn{2}{|c|}{0.036} & 0.097 & 0.192 & \multicolumn{3}{|c|}{0.478} \\
\hline & & & -5.020 & \multicolumn{2}{|c|}{-1.465} & 0.650 & -0.346 & \multicolumn{3}{|c|}{11.870} \\
\hline & & & -0.031 & \multicolumn{2}{|c|}{-0.010} & 0.010 & -0.002 & \multicolumn{3}{|c|}{0.281} \\
\hline \multicolumn{11}{|c|}{ Control variable } \\
\hline \multirow{4}{*}{\multicolumn{2}{|c|}{$\begin{array}{l}\text { Ave.size } \\
\text { Std. sale } \\
\text { Std.ocf } \\
\text { Prop.NI }\end{array}$}} & & 4.005 & \multicolumn{2}{|c|}{5.779} & 7.511 & 5.788 & \multicolumn{3}{|c|}{2.385} \\
\hline & & & 0.140 & \multicolumn{2}{|c|}{0.236} & 0.381 & 0.298 & \multicolumn{3}{|c|}{0.233} \\
\hline & & & 0.044 & \multicolumn{2}{|c|}{0.071} & 0.117 & 0.100 & \multicolumn{3}{|c|}{0.090} \\
\hline & & & 1 & \multicolumn{2}{|c|}{4} & 8 & 4.885 & \multicolumn{3}{|c|}{4.195} \\
\hline \multicolumn{11}{|c|}{ Panel B Pearson Correlations } \\
\hline & & Caq_90 & Ave.fat & Ave.pce & $\begin{array}{c}\text { Ave.fat } \\
\text { sic }\end{array}$ & $\begin{array}{c}\text { Ave.pce } \\
\text { sic }\end{array}$ & Ave.size & Std. sale & Std.ocf & $\begin{array}{c}\text { Prop. } \\
\text { NI }\end{array}$ \\
\hline Caq_90 & $\begin{array}{l}\text { Pearson } \\
\text { Sig }\end{array}$ & 1.000 & & & & & & & & \\
\hline Ave.fat & $\begin{array}{l}\text { Pearson } \\
\text { Sig }\end{array}$ & $\begin{array}{c}-0.185 \\
0.000\end{array}$ & 1.000 & & & & & & & \\
\hline Ave.pce & $\begin{array}{l}\text { Pearson } \\
\text { Sig }\end{array}$ & $\begin{array}{l}0.248 \\
0.000\end{array}$ & $\begin{array}{c}-0.232 \\
0.000\end{array}$ & 1.000 & & & & & & \\
\hline Ave.fat_sic & $\begin{array}{l}\text { Pearson } \\
\text { Sig }\end{array}$ & $\begin{array}{c}-0.206 \\
0.000\end{array}$ & $\begin{array}{l}0.585 \\
0.000\end{array}$ & $\begin{array}{c}-0.325 \\
0.000\end{array}$ & 1.000 & & & & & \\
\hline & Pearson & 0.267 & -0.245 & 0.810 & -0.406 & 1.000 & & & & \\
\hline Ave.pce_sic & Sig & 0.000 & 0.000 & 0.000 & 0.000 & & & & & \\
\hline & Pearson & 0.408 & -0.313 & 0.266 & -0.225 & 0.213 & 1.000 & & & \\
\hline Ave.size & Sig & 0.000 & 0.000 & 0.000 & 0.000 & 0.000 & & & & \\
\hline & Pearson & -0.279 & 0.433 & -0.239 & 0.311 & -0.232 & -0.414 & 1.000 & & \\
\hline sta. sale & Sig & 0.000 & 0.000 & 0.000 & 0.000 & 0.000 & 0.000 & & & \\
\hline & Pearson & -0.372 & 0.231 & -0.165 & 0.166 & -0.158 & -0.602 & 0.428 & 1.000 & \\
\hline Std.ocf & Sig & 0.000 & 0.000 & 0.000 & 0.000 & 0.000 & 000 & 0.000 & & \\
\hline & Pearson & -0.383 & 0.128 & -0.155 & 0.099 & -0.154 & -0.533 & 0.296 & 0.564 & 1.000 \\
\hline Prop.NI & Sig & 0.000 & 0.000 & 0.000 & 0.000 & 0.000 & 0.000 & 0.000 & 0.000 & \\
\hline
\end{tabular}

Variable Definition: $\mathrm{C}_{\mathrm{AQ}}$ is the investment risks proposed by this study. It is the estimated residuals calculated by residuals estimation approach by Francis et.(2005) and is converted into the tolerance range of investors. Ave.fat fixed asset turnover ratio is calculated by revenues divided by fixed assets(Compustat \# 12/ Compustat \#7) and converted into firm level by average. Ave.pce capital expenditure ratio per person is calculated by fixed assets divided by number of employees (Compustat \#7/ Compustat \#29) and converted into firm level by average. Ave.fat_sic difference between fixed asset turnover ratio and industry mean is calculated by fixed asset turnover ratio in firm level minus the mean of fixed asset turnover ratio in such industry. Ave.pce sic difference between capital expenditure ratio per person and industry mean is calculated by capital expenditure ratio per person in firm level minus mean of capital expenditure ratio per person in such industry. Ave.size is firm size. It is calculated by inputting total assets (Compustat \#6) into the natural logarithm function and converted back into firm level by average. Std. sale is standard deviation of revenues. Revenues are deflated by average total assets and obtained the standard deviation. Std.ocf is standard deviation of cash flows. Cash flows are deflated by average total assets and obtained the standard deviation. Prop.NI is the number of deficits. If current earnings equal to 1 , it is converted to firm level by accumulation. 
As for correlation coefficient, only the difference between capital expenditure ratio per person and industry mean has higher correlation coefficient (0.810) among all variables. Other independent variables are lower to moderate correlated. However, the capital expenditure ratio per person and difference between capital expenditure ratio per person and industry mean are not put on the same regression, so there is no collinearity for the variables in this paper. For the correlation between CAQ and accounting signals, fixed asset turnover ratio and difference between fixed asset turnover ratio and industry mean have significant negative correlation, but capital expenditure ratio per person and difference between capital expenditure ratio per person and industry mean have significant positive correlation.

This paper then designs the strategy hierarchy based on the concept of a relative proportion between profit margins and asset turnover ratio, where lower profit margins and higher asset turnover ratio is cost leadership firm, higher profit margins and lower asset turnover ratio is differentiation strategy firm. There are 416 and 1284 samples respectively. Table4 is the regression analysis after classifying the strategies. There are mainly two parts - firm-specific accounting signals and industry-specific accounting signals. In Model1 and Model2, they show the influence of firm-specific accounting signals on investment risks. Regression result shows that no matter in cost leadership strategy (Model1) or differentiation strategy (Model2), if a firm emphasizes on the capital expenditure ratio per person will reduce investment risks. That means no matter which strategy a firm applies, it can reduce investment risks if it focuses on the degree of automation. Therefore we can infer that the improvement in automation can allow the organization to use flexible manufacturing technology to adapt to environmental uncertainty. For example, Foxconn (OEM factory for APPLE) concerned about the investment in automation equipment after a series of suicides in China and increasing salary issues.

For Model3 and Model4, they show the influence of industry-specific accounting signals on investment risks. Regression result shows that in cost leadership strategy firm (Model3), difference between fixed asset turnover ratio and industry mean has significant positive correlation with investment risks. However in differentiation strategy firm (Model4), the correlation is negative. It signifies that if the fixed asset turnover ratio in cost leadership strategy firm is higher than industry mean, the investment risks are higher; while in differentiation strategy firm, the situation is reverse. A firm following cost leadership strategy reduces its production costs and earns by sales at the expense of profits. Hence, enhancing fixed asset turnover ratio can effectively reduce costs. There are two methods to do so: increasing sales with unchanged fixed assets or reducing fixed assets held with unchanged sales. Firms following cost leadership usually use loosen credit policy or benchmark policy to enhance the effective use of fixed assets. However dramatic changes in environment such as the financial tsunami or economic crisis will bring greater operation risks. Porter (1996) mentioned the competitive convergence that rivals imitate one another's improvements in quality or supplier partnerships so that the strategy of each firm tends to be the same. It will lead to wars of attrition that can be stopped only by limiting competition. Hence, for a firm following cost leadership strategy, it produces with high effective method. There will be competitive convergence if a firm emphasizes too much on imitating to improvement quality 
and leads to wars of attrition which causes higher uncertainty in a firm's operation and therefore higher investment risks.

Table 4. Regressions result Where the Dependent Variable is the CAQ and the Independent Variables are Factors of Production_ ROA Model

\begin{tabular}{|c|c|c|c|c|c|c|c|c|}
\hline & \multicolumn{2}{|c|}{ Cost Leadership } & \multicolumn{2}{|c|}{ Differentiation } & \multicolumn{2}{|c|}{ Cost Leadership } & \multicolumn{2}{|c|}{ Differentiation } \\
\hline & \multicolumn{2}{|c|}{ Model1 } & \multicolumn{2}{|c|}{ Model2 } & \multicolumn{2}{|c|}{ Model3 } & \multicolumn{2}{|c|}{ Model4 } \\
\hline & Coef & P-Value & Coef & P-Value & Coef & P-Value & Coef & P-Value \\
\hline Ave.fat & -0.023 & 0.182 & 0.012 & 0.629 & & & & \\
\hline Ave.pce & 2.593 & 0.009 & 1.643 & 0.000 & & & & \\
\hline Ave.fat_sic & & & & & -0.066 & 0.013 & 0.094 & 0.000 \\
\hline Ave.pce_sic & & & & & 0.220 & 0.891 & 0.251 & 0.689 \\
\hline Ave.size & 0.215 & 0.297 & 0.685 & 0.000 & 0.319 & 0.116 & 0.755 & 0.000 \\
\hline Std. sale & -2.078 & 0.205 & -6.034 & 0.000 & -2.667 & 0.099 & -7.051 & 0.000 \\
\hline Std.ocf & -10.323 & 0.080 & -13.753 & 0.000 & -9.491 & 0.110 & -14.629 & 0.000 \\
\hline Prop.NI & -0.429 & 0.000 & -0.294 & 0.000 & -0.448 & 0.000 & -0.304 & 0.000 \\
\hline cons & 9.292 & 0.000 & 5.544 & 0.000 & 9.388 & 0.000 & 6.280 & 0.000 \\
\hline F-value & \multicolumn{2}{|c|}{17.62} & \multicolumn{2}{|c|}{61.71} & \multicolumn{2}{|c|}{16.78} & \multicolumn{2}{|c|}{61.21} \\
\hline P-value & \multicolumn{2}{|c|}{0.000} & \multicolumn{2}{|c|}{0.000} & \multicolumn{2}{|c|}{0.000} & \multicolumn{2}{|c|}{0.000} \\
\hline $\mathrm{R} \wedge 2$ & \multicolumn{2}{|c|}{0.205} & \multicolumn{2}{|c|}{0.225} & \multicolumn{2}{|c|}{0.198} & \multicolumn{2}{|c|}{0.223} \\
\hline Adj $R \wedge 2$ & \multicolumn{2}{|c|}{0.194} & \multicolumn{2}{|c|}{0.221} & \multicolumn{2}{|c|}{0.186} & \multicolumn{2}{|c|}{0.220} \\
\hline
\end{tabular}

a. Variable Definition: $\mathrm{C}_{\mathrm{AQ}}$ is the investment risks proposed by this study. It is the estimated residuals calculated by residuals estimation approach by Francis et.(2005) and is converted into the tolerance range of investors. Ave.fat fixed asset turnover ratio is calculated by revenues divided by fixed assets(Compustat \# 12/ Compustat \#7) and converted into firm level by average. Ave.pce capital expenditure ratio per person is calculated by fixed assets divided by number of employees (Compustat \#7/ Compustat \#29) and converted into firm level by average. Ave.fat_sic difference between fixed asset turnover ratio and industry mean is calculated by fixed asset turnover ratio in firm level minus the mean of fixed asset turnover ratio in such industry. Ave.pce_sic difference between capital expenditure ratio per person and industry mean is calculated by capital expenditure ratio per person in firm level minus mean of capital expenditure ratio per person in such industry. Ave.size is firm size. It is calculated by inputting total assets (Compustat \#6) into the natural logarithm function and converted back into firm level by average. Std. sale is standard deviation of revenues. Revenues are deflated by average total assets and obtained the standard deviation. Std.ocf is standard deviation of cash flows. Cash flows are deflated by average total assets and obtained the standard deviation. Prop.NI is the number of deficits. If current earnings equal to 1 , it is converted to firm level by accumulation.

b. Cost Leadership is cost leadership strategy. Firms with higher fixed asset turnover ratio than industry mean and lower profit margins than industry mean are samples for cost leadership strategy. Differentiation is differentiation strategy. Firms with lower fixed asset turnover ratio than industry mean and higher profit margins than industry mean are samples for differentiation strategy.

By contrast, a firm following differentiation strategy pursues high profit margins and differentiates the market with its uniqueness. The firm can react immediately to customer's demands and produce customized products. Hence, the firm can increase the fixed asset turnover ratio by purchase or upgrading flexible manufacturing system to accommodate to special customized orders and shorten the duration of customer's reaction and thus create higher sales revenues as well as improving its competitiveness to lower the investment risks.

In addition, this paper further analyzes samples surpasses industry mean by ROA to examine if firms with better performance have the same situation as they do before differentiating 
performance. Regression result and Table4 show the same result. When considering firm-specific accounting signals, the capital expenditure ratio per person reduces investment risks. However when considering industry-specific accounting signals, cost leadership strategy tends to have competitive convergence problem. For differentiation strategy, it show an enhancement in effectiveness of fixed assets and we can infer that it improve organization competitiveness.

Table 5. Regressions result Where the Dependent Variable is the CAQ and the Independent Variables are Factors of Production under the firm performance outperform than industry performance_ROA Model

\begin{tabular}{|c|c|c|c|c|c|c|c|c|}
\hline & \multicolumn{2}{|c|}{ Cost Leadership } & \multicolumn{2}{|c|}{ Differentiation } & \multicolumn{2}{|c|}{ Cost Leadership } & \multicolumn{2}{|c|}{ Differentiation } \\
\hline & \multicolumn{2}{|c|}{ Model1 } & \multicolumn{2}{|c|}{ Model2 } & \multicolumn{2}{|c|}{ Model3 } & \multicolumn{2}{|c|}{ Model4 } \\
\hline & Coef & P-Value & Coef & P-Value & Coef & P-Value & Coef & P-Value \\
\hline Ave.fat & -0.013 & 0.506 & 0.014 & 0.590 & & & & \\
\hline Ave.pce & 2.625 & 0.023 & 1.387 & 0.000 & & & & \\
\hline Ave.fat_sic & & & & & -0.068 & 0.025 & 0.094 & 0.000 \\
\hline Ave.pce_sic & & & & & 0.286 & 0.878 & 0.512 & 0.414 \\
\hline Ave.size & 0.141 & 0.594 & 0.595 & 0.000 & 0.255 & 0.327 & 0.636 & 0.000 \\
\hline Std. sale & -1.920 & 0.391 & -7.661 & 0.000 & -2.440 & 0.265 & -8.316 & 0.000 \\
\hline Std.ocf & -34.247 & 0.012 & -20.769 & 0.000 & -34.584 & 0.011 & -22.431 & 0.000 \\
\hline Prop.NI & -0.417 & 0.016 & -0.307 & 0.000 & -0.419 & 0.016 & -0.314 & 0.000 \\
\hline cons & 10.904 & 0.000 & 6.653 & 0.000 & 11.016 & 0.000 & 7.482 & 0.000 \\
\hline F-value & 11 & & 54 & & 10. & & 54. & \\
\hline P-value & 0.0 & & 0.0 & & 0.0 & & 0.0 & \\
\hline $\mathrm{R} \wedge 2$ & 0.2 & & 0.2 & & 0.1 & & 0.2 & \\
\hline Adj $\mathrm{R} \wedge 2$ & 0.1 & & 0.2 & & 0.1 & & 0.2 & \\
\hline
\end{tabular}

a. Variable Definition: $\mathrm{C}_{\mathrm{AQ}}$ is the investment risks proposed by this study. It is the estimated residuals calculated by residuals estimation approach by Francis et.(2005) and is converted into the tolerance range of investors. Ave.fat fixed asset turnover ratio is calculated by revenues divided by fixed assets(Compustat \# 12/ Compustat \#7) and converted into firm level by average. Ave.pce capital expenditure ratio per person is calculated by fixed assets divided by number of employees (Compustat \#7/ Compustat \#29) and converted into firm level by average. Ave.fat_sic difference between fixed asset turnover ratio and industry mean is calculated by fixed asset turnover ratio in firm level minus the mean of fixed asset turnover ratio in such industry. Ave.pce_sic difference between capital expenditure ratio per person and industry mean is calculated by capital expenditure ratio per person in firm level minus mean of capital expenditure ratio per person in such industry. Ave.size is firm size. It is calculated by inputting total assets (Compustat \#6) into the natural logarithm function and converted back into firm level by average. Std. sale is standard deviation of revenues. Revenues are deflated by average total assets and obtained the standard deviation. Std.ocf is standard deviation of cash flows. Cash flows are deflated by average total assets and obtained the standard deviation. Prop.NI is the number of deficits. If current earnings equal to 1 , it is converted to firm level by accumulation.

b. Cost Leadership is cost leadership strategy. Firms with higher fixed asset turnover ratio than industry mean and lower profit margins than industry mean are samples for cost leadership strategy. Differentiation is differentiation strategy. Firms with lower fixed asset turnover ratio than industry mean and higher profit margins than industry mean are samples for differentiation strategy.

\section{Sensitivity Test}

The decomposition of accounting signals is based on ROA in this paper. Soliman (2008) pointed out RNOA decomposition can capture the operation situation without the effects of financial leverage. Hence, this paper employs RNOA to conduct sensitive test. Table6 is the analysis result for RNOA where the regression result indicates capital expenditure ratio per person reduces investment risks no matter for cost leadership strategy or differentiation strategy in firm-specific accounting signals. Compared with cost leadership strategy, firms following differentiation strategy also show the improvement in fixed asset turnover ratio can reduce investment risks. Nevertheless, the industry-specific accounting signals shows influence on investment risks only in differentiation strategy firms. If the firms pursue 
improvement in fixed asset turnover ratio will reduce investment risks. After differentiating samples with better performance (Table7), capital expenditure ratio per person reduces investment risks no matter for cost leadership strategy or differentiation strategy in firm-specific accounting signals.

Table 6. Regressions Where the Dependent Variable is the CAQ and the Independent Variables are Factors of Production _ RNOA Model

\begin{tabular}{|c|c|c|c|c|c|c|c|c|}
\hline & \multicolumn{2}{|c|}{ Cost Leadership } & \multicolumn{2}{|c|}{ Differentiation } & \multicolumn{2}{|c|}{ Cost Leadership } & \multicolumn{2}{|c|}{ Differentiation } \\
\hline & Coef & P-Value & Coef & P-Value & Coef & P-Value & Coef & P-Value \\
\hline Ave.fat & -0.004 & 0.766 & 0.065 & 0.089 & & & & \\
\hline Ave.pce & 2.017 & 0.010 & 1.616 & 0.004 & & & & \\
\hline Ave.fat_sic & & & & & -0.002 & 0.916 & 0.159 & 0.000 \\
\hline Ave.pce_sic & & & & & -0.930 & 0.421 & -0.591 & 0.559 \\
\hline Ave.size & 0.390 & 0.015 & 0.665 & 0.000 & 0.480 & 0.003 & 0.720 & 0.000 \\
\hline Std. sale & 0.318 & 0.815 & -8.548 & 0.001 & -0.333 & 0.803 & -8.595 & 0.000 \\
\hline Std.ocf & -47.455 & 0.000 & -58.036 & 0.000 & -49.537 & 0.000 & -57.381 & 0.000 \\
\hline Prop.NI & -0.294 & 0.002 & -0.292 & 0.007 & -0.314 & 0.001 & -0.301 & 0.005 \\
\hline cons & 8.351 & 0.000 & 9.405 & 0.000 & 8.498 & 0.000 & 10.483 & 0.000 \\
\hline F-value & \multicolumn{2}{|c|}{24.26} & \multicolumn{2}{|c|}{35.33} & \multicolumn{2}{|c|}{22.64} & \multicolumn{2}{|c|}{37.14} \\
\hline P-value & \multicolumn{2}{|c|}{0.000} & \multicolumn{2}{|c|}{0.000} & \multicolumn{2}{|c|}{0.000} & \multicolumn{2}{|c|}{0.000} \\
\hline $\mathrm{R} \wedge 2$ & \multicolumn{2}{|c|}{0.351} & \multicolumn{2}{|c|}{0.210} & \multicolumn{2}{|c|}{0.336} & \multicolumn{2}{|c|}{0.218} \\
\hline Adj $R \wedge 2$ & \multicolumn{2}{|c|}{0.337} & \multicolumn{2}{|c|}{0.204} & \multicolumn{2}{|c|}{0.321} & \multicolumn{2}{|c|}{0.212} \\
\hline
\end{tabular}

a. Variable Definition: $\mathrm{C}_{\mathrm{AQ}}$ is the investment risks proposed by this study. It is the estimated residuals calculated by residuals estimation approach by Francis et.(2005) and is converted into the tolerance range of investors. Ave.fat fixed asset turnover ratio is calculated by revenues divided by fixed assets(Compustat \# 12/ Compustat \#7) and converted into firm level by average. Ave.pce capital expenditure ratio per person is calculated by fixed assets divided by number of employees (Compustat \#7/ Compustat \#29) and converted into firm level by average. Ave.fat_sic difference between fixed asset turnover ratio and industry mean is calculated by fixed asset turnover ratio in firm level minus the mean of fixed asset turnover ratio in such industry. Ave.pce_sic difference between capital expenditure ratio per person and industry mean is calculated by capital expenditure ratio per person in firm level minus mean of capital expenditure ratio per person in such industry. Ave.size is firm size. It is calculated by inputting total assets (Compustat \#6) into the natural logarithm function and converted back into firm level by average. Std. sale is standard deviation of revenues. Revenues are deflated by average total assets and obtained the standard deviation. Std.ocf is standard deviation of cash flows. Cash flows are deflated by average total assets and obtained the standard deviation. Prop.NI is the number of deficits. If current earnings equal to 1 , it is converted to firm level by accumulation.

b. Cost Leadership is cost leadership strategy. Firms with higher fixed asset turnover ratio than industry mean and lower profit margins than industry mean are samples for cost leadership strategy. Differentiation is differentiation strategy. Firms with lower fixed asset turnover ratio than industry mean and higher profit margins than industry mean are samples for differentiation strategy. 
Table 7. Regressions result Where the Dependent Variable is the CAQ and the Independent Variables are Factors of Production under the firm performance outperform than industry performance _ RNOA Model

\begin{tabular}{|c|c|c|c|c|c|c|c|c|}
\hline & \multicolumn{2}{|c|}{ Cost Leadership } & \multicolumn{2}{|c|}{ Differentiation } & \multicolumn{2}{|c|}{ Cost Leadership } & \multicolumn{2}{|c|}{ Differentiation } \\
\hline & Coef & P-Value & Coef & P-Value & Coef & P-Value & Coef & P-Value \\
\hline Ave.fat & -0.032 & 0.332 & 0.086 & 0.309 & & & & \\
\hline Ave.pce & 2.480 & 0.044 & 3.222 & 0.002 & & & & \\
\hline Ave.fat_sic & & & & & -0.032 & 0.523 & 0.092 & 0.219 \\
\hline Ave.pce_sic & & & & & -0.107 & 0.951 & 0.620 & 0.755 \\
\hline Ave.size & 0.243 & 0.389 & 0.736 & 0.022 & 0.376 & 0.185 & 0.743 & 0.019 \\
\hline Std. sale & 2.587 & 0.273 & -8.431 & 0.059 & 1.102 & 0.634 & -8.548 & 0.027 \\
\hline Std.ocf & -57.517 & 0.000 & -67.291 & 0.001 & -59.338 & 0.000 & -75.112 & 0.000 \\
\hline Prop.NI & -0.255 & 0.196 & 0.233 & 0.414 & -0.288 & 0.155 & 0.268 & 0.359 \\
\hline cons & 9.547 & 0.000 & 7.544 & 0.016 & 9.715 & 0.000 & 9.796 & 0.002 \\
\hline F-value & \multicolumn{2}{|c|}{9.47} & \multicolumn{2}{|c|}{13.66} & \multicolumn{2}{|c|}{8.24} & \multicolumn{2}{|c|}{11.75} \\
\hline P-value & \multicolumn{2}{|c|}{0.000} & \multicolumn{2}{|c|}{0.000} & \multicolumn{2}{|c|}{0.000} & \multicolumn{2}{|c|}{0.000} \\
\hline $\mathrm{R}^{\wedge} 2$ & \multicolumn{2}{|c|}{0.339} & \multicolumn{2}{|c|}{0.318} & \multicolumn{2}{|c|}{0.308} & \multicolumn{2}{|c|}{0.286} \\
\hline Adj $R \wedge 2$ & \multicolumn{2}{|c|}{0.303} & \multicolumn{2}{|c|}{0.295} & \multicolumn{2}{|c|}{0.271} & \multicolumn{2}{|c|}{0.262} \\
\hline
\end{tabular}

a. Variable Definition: $\mathrm{C}_{\mathrm{AQ}}$ is the investment risks proposed by this study. It is the estimated residuals calculated by residuals estimation approach by Francis et.(2005) and is converted into the tolerance range of investors. Ave.fat fixed asset turnover ratio is calculated by revenues divided by fixed assets(Compustat \# 12/ Compustat \#7) and converted into firm level by average. Ave.pce capital expenditure ratio per person is calculated by fixed assets divided by number of employees (Compustat \#7/ Compustat \#29) and converted into firm level by average. Ave.fat_sic difference between fixed asset turnover ratio and industry mean is calculated by fixed asset turnover ratio in firm level minus the mean of fixed asset turnover ratio in such industry. Ave.pce_sic difference between capital expenditure ratio per person and industry mean is calculated by capital expenditure ratio per person in firm level minus mean of capital expenditure ratio per person in such industry. Ave.size is firm size. It is calculated by inputting total assets (Compustat \#6) into the natural logarithm function and converted back into firm level by average. Std. sale is standard deviation of revenues. Revenues are deflated by average total assets and obtained the standard deviation. Std.ocf is standard deviation of cash flows. Cash flows are deflated by average total assets and obtained the standard deviation. Prop.NI is the number of deficits. If current earnings equal to 1 , it is converted to firm level by accumulation.

b. Cost Leadership is cost leadership strategy. Firms with higher fixed asset turnover ratio than industry mean and lower profit margins than industry mean are samples for cost leadership strategy. Differentiation is differentiation strategy. Firms with lower fixed asset turnover ratio than industry mean and higher profit margins than industry mean are samples for differentiation strategy.

\section{Test of Risk Confidence Interval for Investors}

This paper applies 90\% confidence interval of investors as the calculation standard for investment risks. To ensure the robustness of the study, we also apply 95\% and 99\% confidence intervals in calculation and regarded as part of the robustness test. Regression result shows 95\% and 99\% confidence intervals have the same result with 90\% confidence intervals. Hence this paper argues that capital expenditure ratio per person for firm-specific accounting signal can reduce investment risks. For industry-specific accounting signals, it focuses more on fixed asset turnover ratio. For firms following cost leadership strategy, there will be competitive convergence problem if the fixed asset turnover ratio surpasses industry mean and therefore increases investment risks. For forms applying differentiation strategy, it will enhance organization competitiveness and reduce investment risks when fixed asset turnover ratio surpasses industry mean.

\section{Research Conclusions}

The earnings information on financial statements is summarized by accruals basis which includes the managers' valuation and estimation on earnings figures. There can be valuation 
or estimation errors intentionally or unintentionally, indirectly leading to information risks when investors use the information. Therefore, Dechow and Dichev (2002) proposed the accrual quality concept by matching of cash flows and accruals earnings which are applied by many subsequent researches as proxy for information risks. Yet investors also evaluate their degree of aversion and tolerance towards risks other than considering only the information on financial statements when they make decisions. Moreover, it has become an important evaluation approach to get an insight into the strategy implementation and internal management activities of a firm from financial statements. Therefore, we apply the capability index of accrual quality which include investors' degree of aversion and tolerance towards risks suggested by Chang et al. (2012) as the proxy for investment risks and review the influence of accounting signals on investment risks by extending the point of view of Soliman (2008).

For the factors of investment management in firm-wise, our result shows that capital expenditure ratio per person can reduce investment risks no matter for firms following cost leadership strategy or differentiation strategy. In another word, the enhancement in automation can assist the firms to use manufacturing technology to adapt to environment uncertainty. In addition, in industry-wise, our result finds that the difference between fixed asset turnover ratio and industry mean plays different roles in cost leadership strategy and differentiation strategy. Samples following cost leadership strategy show competitive convergence effect which is proposed by Porter (1996) when they over-pursue fixed asset turnover ratio. It means firms imitate each other to improve quality, production cycle or supplier partnerships so their strategies tend to be the same and this will lead to wars of attrition so there is no one wins in the market and increase investment risks. For samples following differentiation strategy, improvement in fixed asset turnover ratio can enhance organization competitiveness and reduce investment risks.

To conclude, there are two parts for the practical implications of this paper. In firm-wise, we find that capital expenditure ratio per person can significantly reduce investment risks, simplifying that enhancement in automation equipment or technical equipment can assist firms to handle the uncertainty in environment. A well-known sample is Foxconn which invested over $\$ 10$ billion in machines after the salary increase and labor safety problems. Its main purpose is to reduce labor cost and improve work efficiency by automated manufacturing. Therefore, this paper believes automated manufacturing processes can help firms to effectively accommodate to uncertain environment and quickly adjust the manufacturing pace to meet customer's needs. With the threat of Japanese and Korean styles cars, the Lean Manufacturing at FORD is another example which converts traditional manufacturing to high automated manufacturing.

In industry-wise, we find that difference between fixed asset turnover ratio and industry mean plays different roles in two strategies especially we find there is competitive convergence effect in cost leadership strategy firms. For example, most of the DRAM factories were OEM factories in the past. They lacked the support of the core technique so they could only get orders by lowering their costs. The most direct way to lower costs is plant expansion and therefore increases the effective use of fixed assets to compete with rivals. Therefore, OEM 
factories have high profits during an economy upturn, but they also face great losses during downturn. To avoid this, we think firms following cost leadership strategy should think outside the box and prevent to over-pursue fixed asset turnover ratio and avoid the competitive convergence effect. There are limitations for this research. The classifications of organization strategies are mainly based on the financial ratio in past literature instead of case study, therefore, we fail to probe into a single study sample and make conclusion. In addition, we only analyze samples in long run so the newly established firms might be exempted from our samples. However, these are always some high-growth firms which our conclusions do not include.

\section{References}

Abarbanell, J., \& Bushee, B. (1998). Abnormal returns to a fundamental analysis strategy. The Accounting Review, 73(1), 19-45.

Banker, R. D., Huang, R., \& Natarajan, R. (2009). Incentive Contracting and Value Relevance of Earnings and Cash Flows. Journal of Accounting Research, 47(3), 647-678. http://dx.doi.org/10.1111/j.1475-679X.2009.00335.x

Beaver, W. H. (1998). Financial Reporting: An Accounting Revolution. 3rd edition. Upper Saddle River, NJ: Prentice Hall.

Beaver, W. H. (2002). Perspectives on Recent Capital Market Research. The Accounting Review, 77(2), 453-47. http://dx.doi.org/10.2308/accr.2002.77.2.453

Bowen, R. M., Burgstahler, D., \& Daley, L. (1986). Evidence on the relationships between earnings and various measures of cash flow. The Accounting Review, 61(4), 713-725.

Brealey, R. A., Myers, S. C., \& Allen, F. (2011). Principles of Corporate Finance, 10th Edition, New York: McGraw-Hill Irwin.

Chang, S. H., Huang, S. Y., Chiu, A. A., \& Huang, M. T. (2012). Construction of Investment Risk Measure by the Dispersion Degree of Estimation Errors of Working Capital. Journal of Applied Finance \& Banking, 2(1), 171-195.

Core, J., Guay, W., \& Verdi, R. (2008). Is accruals quality a priced risk factor? Journal of Accounting and Economics, 46(1), 2-22. http://dx.doi.org/10.1016/j.jacceco.2007.08.001

Dechow, P. M., \& Dichev, I. D. (2002). The quality of accruals and earnings: the role of accrual estimation errors. The Accounting Review, 77, 35-59. http://dx.doi.org/10.2308/accr.2002.77.s-1.35

Dechow, P. M., Sloan, R. G., \& Sweeney, A. P., 1996. Causes and consequences of earnings manipulation: an analysis of firms subject to enforcement actions by the SEC. Contemporary Accounting Research, 13(1), 1-36. http://dx.doi.org/10.1111/j.1911-3846.1996.tb00489.x

DeFond, M. L., \& Hung, M. (2003). An empirical analysis of analysts' cash flow forecasts. $\begin{array}{llll}\text { Journal of Accounting and } & \text { Economics, }\end{array}$ http://dx.doi.org/10.1016/S0165-4101(02)00098-8 
Dreyfus, P. (1988). Go with the (cash) flow as company's value analysis tool. Institutional Investor, 22, 55-56.

Fairfield, P. M., \& Yohn, T. L. (2001). Using asset turnover and profit margin to forecast changes in profitability. Review of Accounting Studies, 6(4), 371-385. http://dx.doi.org/10.1023/A:1012430513430

Feltham, G. A., \& Ohlson, J. A. (1995). Valuation and clean surplus accounting for operating and financial activities. Contemporary Accounting Research, 11(2), 689-731. http://dx.doi.org/10.1111/j.1911-3846.1995.tb00462.x

Francis, J., LaFond, R., Olsson, P., \& Schipper, K. (2005). The market pricing of accruals quality. Journal of Accounting and Economics, 39(2), 295-327. http://dx.doi.org/10.1016/j.jacceco.2004.06.003

Ghosh, D., \& Olson, L. (2009). Environmental uncertainty and managers' use of discretionary accruals. Accounting, Organizations and Society, 34(2), 188-205. http://dx.doi.org/10.1016/j.aos.2008.07.001

Horngren, C. T., Datar S. M., \& Rajan M.V. (2012). Cost Accounting A Managerial Emphasis. Fourteenth Edition. Prentice Hall.

Healy, P. M., \& Palepu, K. G. (2001). Information asymmetry, corporate disclosure, and the capital markets: a review of the empirical disclosure literature. Journal of Accounting and Economics, 31(1-3), 405-440. http://dx.doi.org/10.1016/S0165-4101(01)00018-0

Kaplan, R. S., \& Norton, D. P. (2000). Having trouble with your strategy? Then map it. Harvard Business Review, September-October, 49-61

Kim, D., \& Qi, Y. (2010). Accruals Quality, Stock Returns, and Macroeconomic Conditions. The Accounting Review, 85(3), 937-78. http://dx.doi.org/10.2308/accr.2010.85.3.937

Kothari, S. P. (2000). The role of financial reporting in reducing financial risks in the market. in Building an Infrastructure for Financial Stability, edited by E. S. Rosengren and J. S. Jordan. Federal Reserve Bank of Boston Conference Series 44, 89-102

Lev, B., \& Thiagarajan, S. R (1993). Fundamental information analysis. Journal of Accounting Research, 31(2), 190-215. http://dx.doi.org/10.2307/2491270

Mashruwala, C. A., \& Mashruwala, S. D. (2011). The pricing of accruals quality: January vs. the rest of the year. The Accounting Review, 86(4), 1349-1381. http://dx.doi.org/10.2308/accr-10035

McNichols, M. F. (2002). Discussion of the quality of accruals and earnings: The role of accrual estimation errors. The Accounting Review, 77, 61-69. http://dx.doi.org/10.2308/accr.2002.77.s-1.61

Nissim, D., \& Penman, S. H. (2001). Ratio analysis and equity valuation: From research to $\begin{array}{lllll}\text { practice. Review of Accounting } & \text { Studies, } & 6(1), 154 .\end{array}$ http://dx.doi.org/10.1023/A:1011338221623 
Nwaeze, E. T., Yang, S. S. M., \& Yin, Q. J. (2006). Accounting information and CEO compensation: The role of cash flow from operations in the presence of earnings. Contemporary Accounting Research, 227-265. http://dx.doi.org/10.1506/BUQJ-8KUQ-X2TF-K7T4

Ohison, J.A. (1995). Earnings, book values, and dividends in security valuation. Contemporary Accounting Research, 11(2), 661-687. http://dx.doi.org/10.1111/j.1911-3846.1995.tb00461.x

Palepu, G. K., Healy, P. M., Bernard, L. V., \& Peek, E. (2007). Business Analysis and Valuation. IFRS Edition, Thomson Learning, London.

Porter, M. E. (1996). What is strategy? Harvard Business Review, 74(6), 61-78.

Rayburn, J. (1986). The association of operating cash flow and accruals with security returns. Journal of Accounting Research, 24, 112-133. http://dx.doi.org/10.2307/2490732

Soliman, M. (2008). The Use of DuPont Analysis by Market Participants. The Accounting Review, 83(3), 823-853. http://dx.doi.org/10.2308/accr.2008.83.3.823 